Journal of the Egyptian Society of Parasitology, Vol.43, No.3, December 2013

J. Egypt. Soc. Parasitol., 43(3), 2013: 697 - 704

\title{
ACANTHOSTOMUM SPINICEPS (DIGENEA: CRYPTOGONIMIDAE: ACANTHOSTOMINAE), A PARASITE OF THE AFRICAN SNOOK LATES NILOTICUS (PERCIFORMES: LATIDAE). A LIGHT AND SCANNING ELECTRON MICROSCOPIC STUDY By
}

KAREEM MORSY ${ }^{1}$; HODA EL-FAYOUMI ${ }^{2}$ and SARA ALI ${ }^{2}$

Department of Zoology, Faculty of Science, Cairo University ${ }^{1}$ and Department of Zoology, Faculty of Science, Beni Suef University, Egypt Kareemsaid156@yahoo.com

\begin{abstract}
The morphology of the adult stage of Acanthostomum spiniceps recovered from the African snook, Lates niloticus (Perciformes: Latidae) of the river Nile, Egypt was studied with both light and scanning electron microscopy.The most important morphological features differentiating this species are the number of circumoral spines, body shape, ratio of body length to width, sucker sizes, and the presence or absence of spines on the ventral sucker. Sixteen out of forty fish (40\%) was found to be naturally infected with this digenetic trematode belonging to family: Acanthostominae. The infection was recorded in the intestinal wall of the host fish. Body was elongate, 1.203-2.074 mm long, maximum width 0.311-0.534 mm. Oral sucker was terminal, funnel-shaped, $0.201-0.353 \mathrm{~mm}$ long and $0.245-0.310 \mathrm{~mm}$ wide. Simple peribuccal spines 0.042-0.066 mm long. Ventral sucker was circular, $0.110-0.140 \mathrm{~mm}$ long, $0.120-0.204 \mathrm{~mm}$ wide, situated approximately at $1 / 3$ of body length. Ratio of oral and ventral suckers was $1: 0.5$. Testes tandem or slightly diagonal, located near posterior end of body being of irregular rounded shape. Size of anterior testis was $0.130-0.220 \mathrm{~mm}$ long, $0.314-0.358 \mathrm{~mm}$ wide, that of posterior testis was $0.180-0.274 \mathrm{~mm}$ long, $0.390-0.327 \mathrm{~mm}$ wide. Ovary transversely oval, smaller than testes, measured $0.102-0.166 \mathrm{~mm}$ long, $0.100-0.164 \mathrm{~mm}$ wide, situated just anterior to anterior testis. By comparison with some of the previously described species of this genus, the present one showed all morphological characters and the most morphologically similar species was $A$. spiniceps.
\end{abstract}

Key words: Acanthostomum spiniceps, Acanthostominae, Lates niloticus, A light and scanning electron microscopic study.

\section{Introduction}

Lates niloticus is a species of freshwater fish of family Latidae of order Perciformes. It is widespread all over the Afrotropic ecozone. It was originally described as Labrus niloticus, among the marine wrasses, and also referred to as Centropomus niloticus. Common names include African snook, capitaine, Victoria perch (a misleading trade name, as it is not native to Victoria Lake). It is silver in colour with a distinctive dark-black eye, with a bright-yellow outer ring. It reaches a 
maximum length of nearly $2 \mathrm{~m}$ (more than $6 \mathrm{ft}$ ), weighing up to $200 \mathrm{~kg}$. Adult Nile perch occupy all habitats of a lake with sufficient oxygen concentrations, while juveniles are restricted to shallow or nearshore environments.

Genus Acanthostomum was described by Braun (1899) as Distomum or Scyphocephalum while surveying trematodes infecting Testudo matamata. In Egypt, few studies were done on Acanthostomum infecting fish of the River Nile (Fischtal and Kuntz, 1963; Imam et al, 1991; Soliman and El-Damarany, 1995). A. spiniceps was recorded from Bagrus filamentosus (Ariidae) by Tadros et al. (1978) and from Morone labrax (Percichthyidae) by El-Shahawi and Al-Bassel (1992). This species was also recovered by Dollfus (1932) from Bagrus filamentosus (Ariidae) and Chrysichthys furcatus (Ariidae) from Mali and by Pogoreltseva (1952) from Mullus barbatus ponticus (Mullidae) from the Black Sea. Moravec (1976) redescribed A. spiniceps from Bagrus docmac (Ariidae) based on 41 specimens, observing great morphometric variability. They are characterized by elongated bodies, covered with fine spines, more distinct and more numerous on anterior portion of the body; and absent from the posterior quarter. Oral sucker armed with row of large, simple peribuccal spines, ventral one circular approximately at $1 / 3$ of body length. Ratio of oral and ventral suckers 1: 0.5. Mansour (2012) in Egypt reported A. spiniceps in Bagrus bayad and $B$. docmac caught from the River Nile of Damietta branch at Dakahlia Governorate.
In the present study, the natural prevalence of Acanthostomum spiniceps (Digenea: Cryptogonimidae: Acanthostominae) was described during a recent survey from the African snook, Lates niloticus.

\section{Materials and Methods}

During the period from September 2012 to June 2013, forty specimens of the African snook, Lates niloticus (Perciformes: Latidae) were caught from a location along the River Nile at Beni Suef Governorate. They were kept alive in aquaria, immediately transported in water tanks to the research lab at the Zoology Department, Faculty of Science, Beni Suef University. Fish identification was based on Randall (1983) and modern names follow (Froese and Pauly, 2004). The alimentary canal was dissected and trematodes were carefully removed from the stomach and intestines washed out with normal saline and observed alive under a dissecting microscope. Some worms were fixed in alcohol-formalin-acetic acid (AFA) under a slight coverslip pressure and preserved in $75 \%$ ethanol. Whole-mounts were stained in alum carmine, cleared in xylene and mounted in Canada balsam. Identification of the digenea was carried out after Yamaguti (1971), Surekha and Lakshmi (2005). Illustrations were made using a drawing tube. Prevalence, mean abundance and morphometric measurements followed the guidelines of Bush et al, 1997, minimum-and maximum values were given, followed in parentheses by the arithmetic mean. For SEM, specimens were fixed in $4 \%$ 
buffered gluteraldehyde, washed in cacodylate buffer and dehydrated in ascending ethanol series. After passing through an ascending series of Genosolv-D, they were processed in a critical point drier "Bomer-900" with freon 13 and sputter coated with goldpalladium in a Technics Hummer $\mathrm{V}$ and examined with an Etec Autoscan at 20 kV Jeol SEM.

\section{Results}

Sixteen out of forty fish (40\%) were naturally infected with Acanthostomum spiniceps of family: Acanthostominae. The infection was in the intestinal wall of the African snook, Lates niloticus (Perciformes: Latidae).

Morphologically, Body was elongate measured 1.203-2.074 $\mathrm{mm}$ long with a maximum width $0.311-0.534 \mathrm{~mm}$. Oral sucker was terminal, funnel-shaped with $0.201-0.353 \mathrm{~mm}$ long and 0.245 $0.310 \mathrm{~mm}$ wide. Outer surface of sucker armed with row of 23 large, simple peribuccal spines which was 0.042-0.066 mm long. Ventral sucker was circular measured $0.110-0.140 \mathrm{~mm}$ long, 0.120-0.204 mm wide and situated approximately at $1 / 3$ body length. Ratio of oral and ventral suckers 1:0.5 Pharynx large, oval, strongly muscular measured 0.163-0.177 $\mathrm{mm}$ long and 0.150-0.190 mm wide. Oesophagus relatively short. Intestinal bifurcation in front of ventral sucker and intestinal branches run along body to caudal end. Seminal vessicle located posterior to ventral sucker. Testes tandem or slightly diagonal, located near posterior end of body being of irregular rounded shape. Size of anterior testis 0.130-
$0.220 \mathrm{~mm}$ long, $0.314-0.358 \mathrm{~mm}$ wide; posterior testis $0.180-0.274 \mathrm{~mm}$ long, $0.390-0.327 \mathrm{~mm}$ wide. Ovary transversely oval, smaller than testes, measured 0.102-0.166 mm long, 0.100-0.164 mm wide situated just anterior to anterior testis. Uterus filling space delimited by ovary, ventral sucker and vitellaria. Genital pore median, just in front of ventral sucker. Mature eggs yellowbrown. Vitellaria follicular situ-ated on sides of posterior body half extending posteriorly to anterior part of anterior testis. Excretory vesicle open-ed by a median pore on posterior end of body.

\section{Taxonomic position}

Type-host: Lates niloticus (Perciformes: Latidae)

Type-locality: River Nile, Egypt.

Site of infection: Intestine.

Prevalence: 16/40 fish (40\%).

Deposition: at Zoology Museum, Department of Zoology, Faculty of Science, Beni Suef University, Egypt.

Etymology: Specific name derived from the outer surface of sucker armed with row of large, simple peribuccal spines, hence the name spiniceps

\section{Discussion}

The taxonomy of acanthostomatid trematodes is confused, due to genera delimitation. There are several attempts to solve this problem (Yamaguti, 1971; Nasir, 1974; Brooks, 1980), but the unsatisfactory situation in this group of trematodes remains to date. The genus Acanthostomum (Looss, 1899) includes A. spiniceps (Looss, 1896) of family Acanthostominae (Poehe, 1926). 21 species of the same genus were also in- 
cluded; A. absconditum (Looss, 1901), A. atae (Tubangui and Masilun-gan, 1936), A. burminis (Bhalerao, 1926), A. caballeroi (Cruz, 1953), A. coronarium (Cobbold, 1861), A. crocodili Yamaguti, 1954, A. diploporum (Stunkard, 1931), A. clongatum (Tubangui and Masilungan, 1936), A. gncrii (Szidat, 1954), A. gonotyl (Dollfus, 1950), A. gumnarclii (Dollfus, 1950), A. imbutiforme (Molin, 1859), A. indicum (Sinha, 1942), A. marajoantm (de Freitas and Lent, 1938), A. minimum (Stunkard, 1938), A. praeterium (Loo-ss, 1901), A. productum (Odhner, 1902), A. qitasitirm (Nicoll,1918), A. scyplwcephalum (Braun, 1901), A. spiniceps (Looss, 1896) Looss 1899, A. vicinum (Odhner, 1902). Besides, two more species, namely $A$. diploporum (Stunkard, 1931) and A. minimum (Stunkard, 1938) were included by Dollfus (1950) in view of the fact that the vitelline glands extend to posterior extremity in this species. The recorded species is compared with most morphologically similar species, it was distinguished from A. bagri, A. absconditum, A. imbutiforme, A. minimum and A. praeterium by possessing oral spines more than twenty and from A. atac, A. burminis, A. coronarium, A. crocodili, A. diploporum, A. gnerii, A. gymnarclii, A. marajoavum, A. minimum and $A$. scyphocephalum in having a pharynx appreciably smaller than vental sucker. The most morphologically similar species of Acanthostomum was those reported by Fernandes, (2002) except for the number of the cephalic spines which are 27 compared with those of the present species which are 23 .
Thus, by comparison, the present species possessed all morphological characteristics of its genus and the most morphologically similar species was $A$. spiniceps reported by Fernandes (2002) except in number of cephalic spines which were 27 compared to 23 in present species.

\section{Conclusion}

The outcome described species was classified as A. spiniceps with some morphometric differences which may be related to processesing. Since this species was recorded from Lates niloticus for the first time, the present study was reported as a new host record in Egypt.

\section{Acknowledgment}

This work was kindly supported by Faculty of Science, Beni Suef University, Beni Suef Governorate, Egypt.

\section{References}

Bhalerao, GD, 1926: Parasitology. Vol. 18: 4-13. Copyright (C) Cambridge University Press.

Braun, M,1899: Weitere Mitteilungen über endoparasitische Trematoden der Chelonier. Centrbl. f. Bact. Par. und Inf. I, 26:627-32.

Brooks, DR, 1980: Rivission of the acanthostminae Poche, 1926 (Digenea: Cryptogonimidae). Zool. J. Linn. Soc. Wash. 45:53-6.

Bush, AO, Lafferty, KD, Lotz, JM, Shostak, AW, 1997: Parasitology meets ecology on its own terms: Margolis et al. revisited. J. Parasitol. 83:575-583.

Dollfus, RP, 1932: Mission Saharienne Augiéras Draper,1927-1928. Trémato- 
des de mamifères, oiseaux et poissons. Bull. Mus. Nat. Hist. Paris. 4: 555-63. Dollfus, RP, 1950: Trematodes reeoltes an Congo Beige par le Profcsseur Paul Brien (maiaout 1937). Ann. Mus. Congo Beige. 8, Ser. 1, 1:1-133.

El-Shahawi, GAZ, Al-Bassel, DA, 1992: A general survey of the helminth parasites infecting common fishes in some inland water in Egypt. Proc. Zool. Soc. A. R. Egypt, 23: 227-241. Fernandes, BM, Mpinto, RM, Cohen, SC, 2002: Report on two species of digenea from marine fishes in Brazil. Braz. J. Biol. 62, 3: 459-462.

Fischtal, JH, kuntz, RE, 1963: Trematode parasites of fishes from Egypt. Part V. Annotated record of some previously described forms. J. Parasitol. 49: 91-98.

Froese, RU, Piatkowski, S, Garthe, D, Pauly, 2004: Trophic signatures of marine organisms in the Mediterranean as compared with other ecosystems. Belgian J. Zool. 134:31-36.

Imam, EAE, El-Askalany, MA, Rashad, SM, 1991: Studies on helminths parasites of Synodontis schall and $\mathrm{Ba}$ grus bayad from Beni-Suef water resources. Assiut. Vet. Med. J. 24:13752.

Lent, H, Freitas, JFT, 1938a: Pesquisas helminthologicas realisadas no estado do Pará. VI. Acanthocephala Memórias do Instituto Oswaldo Cruz. 33:455-9.

Looss, A, 1901: Über die Fasciolidengenera Stephanochasmus Acanthochasmus und einige andere Centrbl. f. Bact. Par. und Inf. I. 29:595-606 :628-34 : 654-61.
Mansour, MF, 2012: Ultrastructure of the spermatozoon of Acanthostomum spiniceps (Digenea: Acanthostomidae), a parasite of Bagrus spp. (Siluriformes: Bagridae). Parasitol. Res. 110, 4:135762.

Looss, A, 1899: Weitere Beitriige zur Kenntnis der Trematoden fauna Aegyptens. Zool. Jb. 12: 521-784.

Moravec, F, 1976: On two acanthostomatid trematode, Acanthostomum spiniceps Looss, 1896 and A. absconditum Looss, 1901 from African bagrid fishes. Folia. Parasitol. 28:201-6.

Nasir, P, 1974: Revision of genera Acanthostomum (Loss,1899) and Telorchis (Luehe, 1899) (trematoda: digenea) with description of Acanthostomum (acanthostomum) scyphocephalum (Braun, 1899) and Telorchis aculeatus (von Linstow, 1879) (Braun, 1901). Riv. Parassitol. 35:1-22.

Nicoll, MA, 1918: The trematode parasites of North Queensland. IV. Parasites of reptiles and frogs. Parasitol.10: 368-74.

Odhner, T, 1911: Results Swedish Zool. Exped. Egypt, White Nile 1901 Part IV.

Ostrowski de Nunez, M, 1984: Beiträge zur Gattung Acanthostomum und zu den Entwicklungszyklen von $A$. $m a$ rajoarum (Freitas und Lent, 1938) und A. Loossi (Perezvigueras, 1957) in Venezuela. Mitt. a. d. Zool. Museum Berlin.

Poche, D, 1926: Das System der Platodaria. Arch. Naturgesch. 91, A:1-458.

Pogoreltseva, TP, 1952: New trematodes of Black Sea fishes.Trudy Karada- 
gsk Biol. Stantsii NA Ukr. SSR. 12: 34-55.

Randall, JE, 1983: A review of the fishes of the subgenus Goniistius, genus Cheilodactylus with description of Argentina y un intento para aclarar su carácter marino. Revista del Instituto Nacional de Investigaciones de las Ciencias Naturales y Museo Argentino Ciencias Naturales Bernardino Rivadavia, Ciencias Zoológicas. 3:1-85.

Soliman, FM, El-Damarany, M, 1995: Prevalence of helminth infection among some Nile fishes in relation to some biological aspects. J. Egypt. German Soc. Zool. 16: 253-75.

Stunkard , HW, Cable, RM, 1931: Notes on a species of Lernaea parasitic in the larvae of Rana clamitans. J. Parasitol. 18:92-97.

Stunkard, HW, 1938: Parasitic flatworms from Yucatan. Publications of Carnegie Institute of Washington. 491: 33-50.

Surekha, P, Lakshmi, CV, 2005: Lecithochirium testelobatus $\mathrm{n}$. sp (Dige- a new species from Easter Island and Rapa. Occasional Papers of the Bernice P. Bishop Museum 25, 7:1-24.

Szidat, L, 1954: Trematodes nuevos de peces de agua dulce de la República nea: Hemiuridae) from the lizard fish, Saurida undosquamis from Andhrapradesh Coast. J. Parasitol. Dis. 29, 2:1436.

Tadros, G, Iskandar, AR, Wassef, $\mathbf{N}$ A, 1978: On some intestinal trematodes from the Nile and Red Sea fishes with a histopathological study of their habitat. J. Egypt. Soc. Parasitol. 8:38392.

Tubangui, MA, Masiluñgan, VA, 1936: Trematode parasites of Philippine vertebrates, VIII. Flukes from a cobra and a crocodile. Philipp. J. Sci. 60:255-66.

Yamguti, S, 1954: Systema helminthum. Part 1. Digenetic trematodes of fishes, Tokyo.

Yamaguti, S, 1971: Synopsis of digenetic trematodes of vertebrates. Vol. 1. Keigaku, Tokyo.

\section{Explanation of Figures}

Figs.1-4: Photomicrographs of adult digenetic trematode Acanthostomum spiniceps. 1 Whole mount preparation of worm with an anterior oral sucker (OS) surrounded by a row of cephalic spines (SP), a ventral sucker (VS) in front of pharynx (PH), two intestinal caeca (IC) runs along two lateral sides of body ended blindly, two testes (TE) arranged in tandem, a spherical ovary (OV) in front of anterior testis, vittelaria (VT) laterally situated and occupied body posterior side, uterus (UT) fills most of space between ventral sucker and ovary. 2-4 High magnifications: 2 Anterior part showing row of cephalic spines surrounding oral sucker. 3 Cephalic spines (SP). 4 Posterior part of worm showing ttwo tandem testis (TE) and ovary (OV).

Figs.5-8: SEM showing 5 adult worm. 6-8 High magnifications of: 6 Ventral sucker (VS), 7 Oral sucker (OS) with surrounding cephalic spines (SP), 8 Cephalic spines (SP).

Fig. 9: Line diagram of adult Acanthostomum spiniceps. EX Excretory pore. 

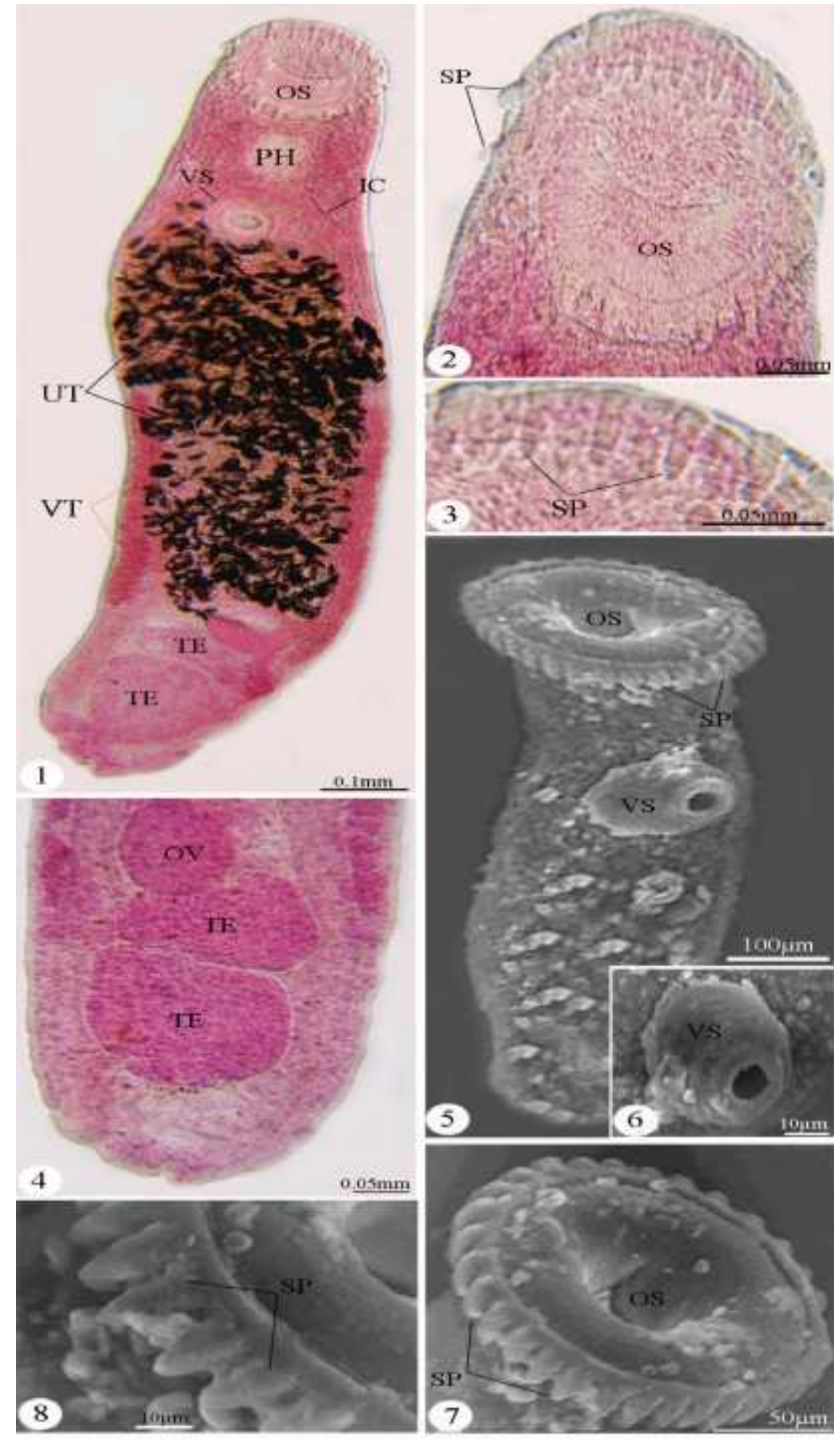


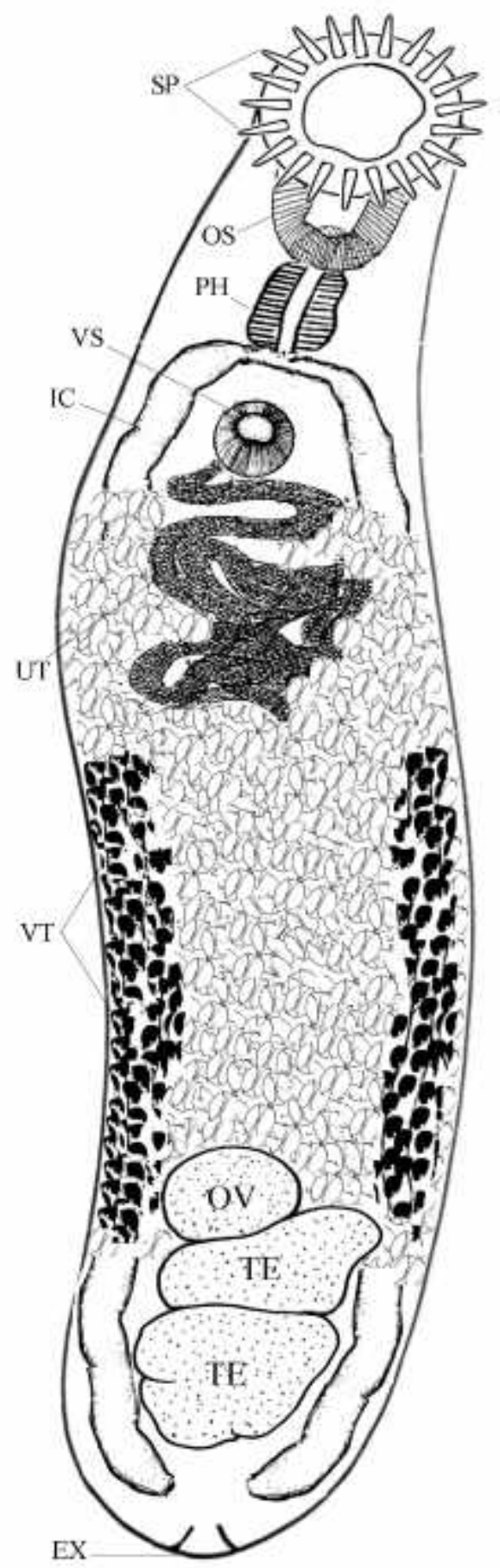

Fig. 9 